\title{
Studies on Genetic Variability, Heritability and Genetic Advance for Growth, Yield and Quality Parameters among Orange Flesh Sweet Potato [Ipomoea batatas (L.) Lam.] Genotypes
}

\author{
Meenakshi Badu $^{1 *}$, P. Ashok ${ }^{1}$, T.S.K.K. Kiran Patro ${ }^{1}$ and K. Sasikala ${ }^{2}$ \\ ${ }^{1}$ Department of Horticulture, ${ }^{2}$ Department of Agronomy, \\ Dr. Y.S.R. Horticultural University, Andhra Pradesh-534 101, India \\ *Corresponding author
}

\section{A B S T R A C T}

The present investigation was undertaken to estimate the genetic variability, heritability and genetic advance for quantitative and qualitative traits among 25 genotypes of orange flesh sweet potato [Ipomoea batatas (L.) Lam.] in a randomized block design with three replications during kharif 2015-16 at College of Horticulture, Venkataramannagudem, Dr. Y.S.R. Horticultural University. Analysis of variance revealed significant differences among the genotypes for all the traits under study indicating, the presence of sufficient variability in the studied material. High magnitude of PCV and GCV were observed for width of leaf lobe, leaf area, total leaf dry weight, chlorophyll a, chlorophyll b, total chlorophyll, length of vine, internodal length, number of branches per plant, fresh weight of whole plant, dry weight of whole plant, fresh weight of root, dry weight of root, leaf area index, specific leaf area, specific leaf weight, crop growth rate, net assimilation rate, reducing sugar, non-reducing sugar, total sugar, $\beta$-carotene, number of root tubers per plant, root tuber girth, root tuber yield per plant and root tuber yield per hectare suggesting the existence of wide range of genetic variability in the germplasm for these traits and thus the scope for improvement of these characters through simple selection would be better. High heritability $\left(\mathrm{h}^{2}\right)$ estimates $(>60 \%)$ coupled with high estimates from genetic gain as percent of mean $(>20 \%)$ were observed for width of leaf lobe, petiole length, leaf area, total leaf dry weight, chlorophyll a, chlorophyll b, total chlorophyll, length of vine, internodal length, number of branches per plant, fresh weight of whole plant, dry weight of whole plant, fresh weight of root, dry weight of root, leaf area index, specific leaf area, specific leaf weight, crop growth rate, net assimilation rate, starch, reducing sugar, nonreducing sugar, total sugar, $\beta$-carotene, number of root tubers per plant, root tuber length, root tuber girth, root tuber yield per plant and root tuber yield per hectare indicated that the heritability is due to additive gene effects which may be improved through simple plant selection methods.

\section{Introduction}

Sweet potato [Ipomoea batatas (L.) Lam.] is a dicotyledonous plant belonging to the family Convolvulaceae. This family includes about 55 genera and more than 1000 species.
However, only Ipomoea batatas is of economic importance as a source of food (Onwueme and Charles, 1994). The amount of variability that exists in the germplasm 
collections of any crop is of utmost importance towards breeding for better varieties. Particularly, genetic variability for a given character is a basic prerequisite for its improvement by systematic breeding.

Sweet potato is a highly heterozygous and cross-pollinated crop in which many of the traits show continuous variation. Since it is highly heterozygous, there is extensive variability within the species, which is available for exploitation by plant breeders (Jones et al., 1986). Hence, consideration of quantitative approaches for exploitation of the extensive genetic variability available in sweet potato is of utmost importance, which in turn is dependent on good estimates of the genetic parameters. Estimates of genetic parameters serve as a base for selection and hybridization as the degree of variability for a given character is a basic prerequisite for its improvement. Although several sweet potato germplasm accessions have been introduced from International Potato Center (CIP), International Institute for Tropical Agriculture (IITA), Asian Vegetable Research and Development Center (AVRDC) and a considerable amount have been collected from farmers field for evaluation and utilization, information on the nature and extent of variability among these collections for traits of economic importance is lacking.

Thus, this study was undertaken to estimate the nature and magnitude of variability for yield and yield related characters with the help of genetic parameters as such as phenotypic as well as genotypic coefficients of variation, heritability and genetic advance. Evaluation and characterization of genotypes is necessary to describe their performance in terms of growth, yield and quality parameters. Yield is a complex character and its direct improvement is difficult (Jindal et al., 2010). Genetic variability available within the sweet potato genotypes has not been fully explored and screened. Therefore, this genetic wealth has not been fully exploited and should offer interesting possibilities for the future. The genetic parameters such as heritability, genetic advance, genotypic and phenotypic coefficients of variation provide an effective tool in the hands of a breeder to select a genotype having the most desirable traits for yield.

\section{Materials and Methods}

The experiment was conducted from August, 2015 to December, 2015 at experimental farm of the Department of Vegetable Science, College of Horticulture, Dr. Y.S.R. Horticultural University, Andhra Pradesh, India. The location is at $16^{\circ} 83^{\prime} \mathrm{N}$ latitude, $81^{\circ} 50^{\prime} \mathrm{E}$ longitude, and $34 \mathrm{~m}$ above mean sea level. The soil was a red sandy loam. Well matured healthy and disease-free cuttings, $20-30 \mathrm{~cm}$ in length, of the previous season for each genotype were planted in a nursery, with the same soil type, at a $30 \times 20 \mathrm{~cm}$ spacing on a raised bed and provided with $5 \mathrm{~L} \cdot \mathrm{day}^{-1}$ of water from a watering can. When vines reached $1 \mathrm{~m}$ in length, cuttings were made and planted in a different nursery with the same spacing. The same type of field soil was thoroughly ploughed to a depth of $30 \mathrm{~cm}$ and brought to good tilth. Synthetic fertilizer of $\mathrm{N}-\mathrm{P}-\mathrm{K}$, 60: $25: 50 \mathrm{~kg} \cdot \mathrm{ha}^{-1}$, respectively, was applied. The single superphosphate was applied prior to transplanting and urea and muriate of potash were applied by sidedressings one month after transplanting. Twenty five genotypes of orange flesh sweet potato (Table 1) were planted in a randomized complete block design with three replications in $2 * 2.5 \mathrm{~m}^{2}$ plots. Seven-week-old cuttings of at least $20-30 \mathrm{~cm}$ length, with three to four nodes, were transplanted manually at a spacing of $60 \times 20 \mathrm{~cm}$ between and within rows and $5 \mathrm{~cm}$ deep in the main field. Plots were kept free from weeds by regular hand weeding. Five plants of each genotype from the middle two rows in each replication were used for observations. 


\section{Statistical analysis}

Phenotypic and genotypic coefficients of variation (PCV and GCV) were computed according to Burton and Devane (1953). Heritability in broad sense was estimated as per Allard (1960). Genetic advance was estimated as per the formula proposed by Lush (1940). The range of genetic advance as per cent of mean was classified as low (Less than 10\%), moderate $(10-20 \%)$ and high (more than 20\%) suggested by Johnson et al., (1955).

\section{Results and Discussion}

The analysis of variance (ANOVA) showed highly significant differences among the genotypes for all the yield and yield component traits studied (Table 2). These findings are in line with earlier reports of Mohanty et al., (2016).

The studies suggested that it is possible to isolate superior genotypes during the selection process. Genetic variability is a basic information needed for the breeders to improve the crops by adopting appropriate method of selection based on variability that exist in the material. In the present study, wide variability was recorded for petiole length, leaf area, total leaf dry weight, length of vine, fresh weight of whole plant, dry weight of whole plant, fresh weight of root, fry weight of root, leaf area index, specific leaf area, net assimilation rate, total sugar, $\beta$ carotene and number of root tubers per plant (Tables 3 and 4). Higher magnitude of PCV (phenotypic coefficient of variation) and GCV (genotypic coefficient of variation) (> 20\%) were observed for width of leaf lobe (48.66 and $47.86 \%$ ), leaf area (77.24 and $75.56 \%$ ), total leaf dry weight(30.43 and $23.74 \%$ ), chlorophyll a (38.79 and $33.27 \%)$, chlorophyll b (40.54 and $39.51 \%)$, total chlorophyll (38.12 and $36.25 \%$ ), length of vine (25.61and $23.77 \%$ ), internodal length (36.53 and $35.74 \%$ ), number of branches per plant (23.41 and 20.98\%), fresh weight of whole plant (27.76 and $25.36 \%$ ), dry weight of whole plant (25.58 and $23.21 \%$ ), fresh weight of root (38.34 and $37.85 \%)$, dry weight of root (39.73 and $38.80 \%$ ), leaf area index $(77.24$ and $75.56 \%)$, specific leaf area (98.35 and $97.77 \%$ ), specific leaf weight (118.94 and $117.27 \%$ ), crop growth rate (43.95 and $40.97 \%$ ), net assimilation rate (136.51 and $135.94 \%)$, reducing sugar (32.46 and $30.76 \%$ ), non-reducing sugar (54.65 and $53.80 \%)$, total sugar (27.28 and $26.10 \%), \beta-$ carotene (30.34 and $29.82 \%$ ), number of root tubers per plant (50.55 and $46.52 \%)$, root tuber girth (22.58 and $21.58 \%)$, root tuber yield per plant (50.23 and $49.03 \%)$ and root tuber yield per hectare (42.98 and $42.41 \%$ ) indicating the existence of wide range of genetic variability in the germplasm for these traits (Tables 3 and 4). High GCV and PCV values indicating large amount of variation and consequently more scope for their improvement through selection (Biradar et al., 1978) in cassava.

These findings are in agreement with results of Thamburaj and Muthukrishnan (1978) for number of branches per plant, girth of tuber, Shivanand et al., (2015) for leaf area, leaf area index, specific leaf area, specific leaf weight and net assimilation rate in ridge gourd. The estimates of PCV and GCV were moderate for petiole length $(19.10$ and $17.87 \%)$, relative growth rate (18.44 and $12.80 \%)$, starch content (19.09 and $18.38 \%)$ and root tuber length (15.08 and 13.63\%).

With the genotypic coefficient of variation alone, it is difficult to determine the relative amount of heritable and non- heritable components of variations present in the population. Estimates of heritability and genetic advance would supplement this parameter. 
Int.J.Curr.Microbiol.App.Sci (2017) 6(9): 1894-1903

Table.1 Genotypes of orange flesh sweet potato

\begin{tabular}{|c|c|c|}
\hline Treatment & Name of genotypes & Source \\
\hline $\mathrm{T}_{1}$ & ST-14 & CTCRI regional centre, Bhubaneswar, Odisha \\
\hline $\mathrm{T}_{2}$ & Sree Kanaka & -do- \\
\hline $\mathrm{T}_{3}$ & SWA-2 & -do- \\
\hline $\mathrm{T}_{4}$ & Kamala Sundari & -do- \\
\hline $\mathrm{T}_{5}$ & CIP-440127 & -do- \\
\hline $\mathrm{T}_{6}$ & ACC-22 & AICRP on tuber crops, Rajendranagar, Hyderabad \\
\hline $\mathrm{T}_{7}$ & ACC-11 & -do- \\
\hline $\mathrm{T}_{8}$ & Kiran & - do- \\
\hline $\mathrm{T}_{9}$ & Gouri & CTCRI regional centre, Bhubaneswar, Odisha \\
\hline $\mathrm{T}_{10}$ & $\mathrm{CO}-1$ & AICRP on tuber crops, Rajendranagar, Hyderabad \\
\hline $\mathrm{T}_{11}$ & VRSP-1 & AICRP on tuber crops, Venkataramannagudem \\
\hline $\mathrm{T}_{12}$ & VRSP-2 & -do- \\
\hline $\mathrm{T}_{13}$ & ACC-5 & -do- \\
\hline $\mathrm{T}_{14}$ & VRSP-3 & -do- \\
\hline $\mathrm{T}_{15}$ & VRSP-4 & -do- \\
\hline $\mathrm{T}_{16}$ & VRSP-5 & -do- \\
\hline $\mathrm{T}_{17}$ & VRSP-6 & -do- \\
\hline $\mathrm{T}_{18}$ & VRSP-7 & -do- \\
\hline $\mathrm{T}_{19}$ & VRSP-8 & -do- \\
\hline $\mathrm{T}_{20}$ & VRSP-9 & -do- \\
\hline $\mathrm{T}_{21}$ & VRSP-10 & -do- \\
\hline $\mathrm{T}_{22}$ & VRSP-11 & -do- \\
\hline $\mathrm{T}_{23}$ & VRSP-12 & -do- \\
\hline $\mathrm{T}_{24}$ & VRSP-13 & -do- \\
\hline $\mathrm{T}_{25}$ & VRSP-14 & -do- \\
\hline
\end{tabular}


Table.2 Analysis of variance for quantitative and qualitative traits in

Orange flesh sweet potato genotypes

\begin{tabular}{|c|c|c|c|c|}
\hline \multirow{2}{*}{$\begin{array}{c}\text { S. } \\
\text { No }\end{array}$} & \multirow[t]{2}{*}{ Character } & \multicolumn{3}{|c|}{ Mean sum of squares } \\
\hline & & $\begin{array}{c}\text { Replications (df } \\
=2 \text { ) }\end{array}$ & $\begin{array}{l}\text { Treatments }(\mathrm{df}= \\
\text { 24) }\end{array}$ & Error $(\mathrm{df}=48)$ \\
\hline 1. & Length of leaf lobe $(\mathrm{cm})$ & 2.042 & $65.722^{*}$ & 17.718 \\
\hline 2. & Width of leaf lobe $(\mathrm{cm})$ & 0.499 & $484.669^{* *}$ & 10.776 \\
\hline 3. & Petiole length $(\mathrm{cm})$ & 3.714 & $1,286.205^{* *}$ & 116.559 \\
\hline 4. & Leaf area $\left(\mathrm{cm}^{2}\right)$ & $190,928,114.929$ & $76,023,661,355.737$ & $\begin{array}{c}2,250,813,536.2 \\
46\end{array}$ \\
\hline 5. & Total leaf dry weight $(\mathrm{g})$ & 960.204 & $78,989.419^{* * *}$ & $27,880.402$ \\
\hline 6. & Chlorophyll a (mg/g) & 0.070 & $2.480^{* * *}$ & 0.530 \\
\hline 7. & Chlorophyll b (mg/g) & 0.023 & $1.947^{* *}$ & 0.067 \\
\hline 8. & Total chlorophyll (mg/g) & 0.069 & $8.648^{* *}$ & 0.590 \\
\hline 9. & length of vine $(\mathrm{cm})$ & $5,388.734$ & $223,550.847^{* *}$ & $22,657.417$ \\
\hline 10. & Internodal length $(\mathrm{cm})$ & 6.423 & $159.528^{* *}$ & 4.692 \\
\hline 11. & No. of branches per plant & 24.167 & $375.025^{* *}$ & 56.625 \\
\hline 12. & $\begin{array}{l}\text { Fresh weight of whole plant } \\
(\mathrm{g})\end{array}$ & $104,849.673$ & $3,798,111.860^{* *}$ & $470,472.805$ \\
\hline 13. & Dry weight of whole plant $(\mathrm{g})$ & $9,463.304$ & $306,511.943^{* *}$ & $40,868.097$ \\
\hline 14. & Fresh weight of root $(\mathrm{g})$ & $104,475.153$ & $4,783,577.917^{* *}$ & $83,702.743$ \\
\hline 15. & Dry weight of root $(\mathrm{g})$ & $6,889.731$ & $611,042.528^{* *}$ & $19,377.061$ \\
\hline 16. & Leaf area index & 132.589 & $52,794.216^{* *}$ & $1,563.067$ \\
\hline 17. & Specific leaf area $\left(\mathrm{cm}^{2} / \mathrm{g}\right)$ & $2,271.798$ & $11,754,294.979^{* *}$ & $92,943.478$ \\
\hline 18. & Specific leaf weight $\left(\mathrm{g} / \mathrm{cm}^{2}\right)$ & 0.000 & $0.005^{* *}$ & 0.000 \\
\hline 19. & Crop growth rate $\left(\mathrm{g} / \mathrm{m}^{2} / \mathrm{d}\right)$ & $2,825.822$ & $40,928.943^{* *}$ & $3,907.663$ \\
\hline 20. & Relative growth rate $(\mathrm{mg} / \mathrm{g} / \mathrm{d})$ & 21.503 & $2,337.407^{*}$ & $1,234.160$ \\
\hline 21. & $\begin{array}{l}\text { Net assimilation rate } \\
\left(\mathrm{mg} / \mathrm{cm}^{2} / \mathrm{d}\right)\end{array}$ & 161.834 & $65,200.250^{* * *}$ & 364.694 \\
\hline 22. & Starch $(\%)$ & 3.260 & $635.227^{* *}$ & 32.120 \\
\hline 23. & Reducing sugar (\%) & 1.118 & $119.170^{* * *}$ & 8.672 \\
\hline 24. & Non-reducing sugar (\%) & -2.954 & $-448.145^{* *}$ & -3.138 \\
\hline 25. & Total sugar (\%) & 0.099 & $172.407^{* * *}$ & 10.331 \\
\hline 26. & $\beta$-carotene (mg/100g f.w.) & 0.064 & $156.013^{* *}$ & 3.649 \\
\hline 27. & No. of root tubers per plant & 0.987 & $378.587^{* *}$ & 43.013 \\
\hline 28. & Root tuber length $(\mathrm{cm})$ & 7.293 & $388.922^{* * *}$ & 54.107 \\
\hline 29. & Root tuber girth $(\mathrm{cm})$ & 1.637 & $1,229.213^{* *}$ & 75.423 \\
\hline 30. & Root tuber yield per plant (g) & $3,975.440$ & $5,758,508.213^{* *}$ & $187,705.227$ \\
\hline 31. & Root tuber yield (t/ha) & 8.167 & $9,383.431^{* *}$ & 169.000 \\
\hline
\end{tabular}

$*, * *=$ significant at $5 \%$ and $1 \%$ level respectively. 
Table.3 Estimates of variability, heritability and genetic advance as per cent of mean for Different characters in orange flesh sweet potato genotypes

\begin{tabular}{|c|c|c|c|c|c|c|c|c|}
\hline \multirow[t]{2}{*}{ Character } & \multicolumn{2}{|c|}{ Range } & \multirow[t]{2}{*}{ Mean } & \multirow{2}{*}{$\begin{array}{r}\text { PCV } \\
(\%)\end{array}$} & \multirow{2}{*}{$\begin{array}{c}\text { GCV } \\
(\%)\end{array}$} & \multirow[t]{2}{*}{$h^{2}(\%)$} & \multirow{2}{*}{$\begin{array}{c}\text { Genetic } \\
\text { Advance }\end{array}$} & \multirow{2}{*}{$\begin{array}{l}\text { GA as } \\
\% \text { of } \\
\text { mean }\end{array}$} \\
\hline & $\begin{array}{l}\text { Maxi } \\
\text { mum }\end{array}$ & $\begin{array}{c}\text { Minimu } \\
\mathrm{m}\end{array}$ & & & & & & \\
\hline $\begin{array}{l}\text { Length of } \\
\text { leaf lobe } \\
(\mathrm{cm})\end{array}$ & 9.1 & 12.7 & 10.82 & 9.94 & 8.20 & 68.14 & 1.51 & 13.96 \\
\hline $\begin{array}{l}\text { Width of leaf } \\
\text { lobe }(\mathrm{cm})\end{array}$ & 1.3 & 10.7 & 5.39 & 48.66 & 47.86 & 96.73 & 5.22 & 96.98 \\
\hline $\begin{array}{l}\text { Petiole length } \\
(\mathrm{cm})\end{array}$ & 13.4 & 34.4 & 23.10 & 19.10 & 17.87 & 87.53 & 7.95 & 34.44 \\
\hline $\begin{array}{c}\text { Leaf area } \\
\left(\mathrm{cm}^{2}\right)\end{array}$ & 4956.3 & 146493.1 & 42685.43 & 77.24 & 75.56 & 95.68 & $64,992.40$ & 152.25 \\
\hline $\begin{array}{c}\text { Total leaf dry } \\
\text { weight }(\mathrm{g})\end{array}$ & 51.9 & 185.0 & 126.59 & 30.43 & 23.74 & 60.86 & 48.30 & 38.16 \\
\hline $\begin{array}{c}\text { Chlorophyll a } \\
(\mathrm{mg} / \mathrm{g})\end{array}$ & 0.10 & 0.78 & 0.52 & 38.79 & 33.27 & 73.58 & 0.31 & 58.80 \\
\hline $\begin{array}{c}\text { Chlorophyll } \\
\text { b (mg/g) }\end{array}$ & 0.10 & 0.67 & 0.41 & 40.54 & 39.51 & 95.01 & 0.32 & 79.35 \\
\hline $\begin{array}{c}\text { Total } \\
\text { chlorophyll } \\
(\mathrm{mg} / \mathrm{g})\end{array}$ & 1.45 & 0.21 & 0.93 & 38.12 & 36.25 & 90.41 & 0.66 & 71.00 \\
\hline $\begin{array}{l}\text { Length of } \\
\text { vine }(\mathrm{cm})\end{array}$ & 125.0 & 372.4 & 228.27 & 25.61 & 23.77 & 86.19 & 103.83 & 45.47 \\
\hline $\begin{array}{c}\text { Internodal } \\
\text { length }(\mathrm{cm})\end{array}$ & 2.7 & 7.9 & 4.13 & 36.53 & 35.74 & 95.71 & 2.97 & 72.04 \\
\hline $\begin{array}{c}\text { Number of } \\
\text { branches per } \\
\text { plant }\end{array}$ & 6.5 & 16.2 & 10.41 & 23.41 & 20.98 & 80.32 & 4.051 & 38.74 \\
\hline $\begin{array}{c}\text { Fresh weight } \\
\text { of whole } \\
\text { plant }(\mathrm{g})\end{array}$ & 475.5 & 1380.4 & 876.93 & 27.76 & 25.36 & 83.46 & 418.65 & 47.74 \\
\hline $\begin{array}{l}\text { Dry weight } \\
\text { of whole } \\
\text { plant }(\mathrm{g})\end{array}$ & 153.1 & 410.0 & 271.47 & 25.58 & 23.21 & 82.35 & 117.83 & 43.40 \\
\hline $\begin{array}{c}\text { Fresh weight } \\
\text { of root (g) }\end{array}$ & 287.0 & 1097.3 & 677.94 & 38.34 & 37.85 & 97.42 & 521.78 & 76.96 \\
\hline $\begin{array}{l}\text { Dry weight } \\
\text { of root }(\mathrm{g})\end{array}$ & 108.2 & 371.0 & 235.40 & 39.73 & 38.80 & 95.38 & 183.87 & 78.07 \\
\hline $\begin{array}{l}\text { Leaf area } \\
\text { index }\end{array}$ & 4.1 & 122.0 & 35.50 & 77.24 & 75.56 & 95.68 & 54.160 & 152.25 \\
\hline
\end{tabular}


Table.4 Estimates of variability, heritability and genetic advance as per cent of mean for Different characters in orange flesh Sweet potato genotypes

\begin{tabular}{|c|c|c|c|c|c|c|c|c|}
\hline \multirow[t]{2}{*}{ Character } & \multicolumn{2}{|c|}{ Range } & \multirow[t]{2}{*}{ Mean } & \multirow{2}{*}{$\begin{array}{l}\text { PCV } \\
(\%)\end{array}$} & \multirow{2}{*}{$\begin{array}{c}\text { GCV } \\
(\%)\end{array}$} & \multirow{2}{*}{$\begin{array}{l}\mathbf{h}^{2} \\
(\%)\end{array}$} & \multirow{2}{*}{$\begin{array}{c}\text { Genetic } \\
\text { Advanc } \\
\text { e }\end{array}$} & \multirow{2}{*}{$\begin{array}{c}\text { GA as \% } \\
\text { of mean }\end{array}$} \\
\hline & Maximum & Minimum & & & & & & \\
\hline $\begin{array}{l}\text { Specific } \\
\text { leaf area } \\
\left(\mathrm{cm}^{2} / \mathrm{g}\right)\end{array}$ & 30.3 & 1695.7 & $\begin{array}{c}412.4 \\
0\end{array}$ & 98.35 & 97.77 & 98.82 & 825.78 & 200.23 \\
\hline $\begin{array}{l}\text { Specific } \\
\text { leaf weight } \\
\left(\mathrm{g} / \mathrm{cm}^{2}\right)\end{array}$ & 0.001 & 0.033 & 0.008 & 118.94 & 117.27 & 97.20 & 0.01 & 238.17 \\
\hline $\begin{array}{l}\text { Crop } \\
\text { growth rate } \\
\left(\mathrm{g} / \mathrm{m}^{2} / \mathrm{d}\right)\end{array}$ & 16.6 & 93.4 & 56.70 & 43.95 & 40.97 & 86.92 & 44.68 & 78.70 \\
\hline $\begin{array}{l}\text { Relative } \\
\text { growth rate } \\
(\mathrm{mg} / \mathrm{g} / \mathrm{d})\end{array}$ & 27.0 & 49.6 & 38.17 & 18.44 & 12.80 & 48.16 & 6.98 & 18.30 \\
\hline $\begin{array}{c}\text { Net } \\
\text { assimilatio } \\
\mathrm{n} \text { rate } \\
\left(\mathrm{mg} / \mathrm{cm}^{2} / \mathrm{d}\right)\end{array}$ & 3.2 & 132.1 & 22.07 & 136.51 & 135.94 & 99.16 & 61.64 & 278.86 \\
\hline Starch (\%) & 2.0 & 9.0 & 4.78 & 19.09 & 18.38 & 92.78 & 5.81 & 36.48 \\
\hline $\begin{array}{l}\text { Reducing } \\
\text { sugar }(\%)\end{array}$ & 12.0 & 21.9 & 16.44 & 32.46 & 30.76 & 89.82 & 2.46 & 60.07 \\
\hline $\begin{array}{c}\text { Non- } \\
\text { reducing } \\
\text { sugar }(\%)\end{array}$ & 11.0 & 30.3 & 18.84 & 54.65 & 53.80 & 96.91 & 1.86 & 109.10 \\
\hline $\begin{array}{c}\text { Total sugar } \\
(\%)\end{array}$ & 210.0 & 986.7 & $\begin{array}{c}572.1 \\
8\end{array}$ & 27.28 & 26.10 & 91.52 & 3.00 & 51.44 \\
\hline $\begin{array}{c}\beta \text {-carotene } \\
\text { (mg/100g } \\
\text { f.w.) }\end{array}$ & 11.0 & 41.3 & 26.79 & 30.34 & 29.82 & 96.57 & 2.96 & 60.37 \\
\hline $\begin{array}{l}\text { No. of root } \\
\text { tubers per } \\
\text { plant }\end{array}$ & 10.8 & 23.3 & 15.94 & 50.55 & 46.52 & 84.69 & 4.22 & 88.20 \\
\hline $\begin{array}{l}\text { Root tuber } \\
\text { length }(\mathrm{cm})\end{array}$ & 2.8 & 7.1 & 4.13 & 15.08 & 13.63 & 81.68 & 4.17 & 25.38 \\
\hline $\begin{array}{l}\text { Root tuber } \\
\text { girth }(\mathrm{cm})\end{array}$ & 0.4 & 3.8 & 1.71 & 22.58 & 21.58 & 91.32 & 8.00 & 42.49 \\
\hline $\begin{array}{l}\text { Root tuber } \\
\text { yield per } \\
\text { plant }(\mathrm{g})\end{array}$ & 3.7 & 8.4 & 5.84 & 50.23 & 49.03 & 95.26 & 563.96 & 98.58 \\
\hline $\begin{array}{l}\text { Root tuber } \\
\text { yield }(\mathrm{t} / \mathrm{ha})\end{array}$ & 2.50 & 8.30 & 4.91 & 42.98 & 42.41 & 97.34 & 23.09 & 86.20 \\
\hline
\end{tabular}


The heritability in broad sense ranged for the characters from 48.16 per cent for relative growth rate to 99.16 per cent for net assimilation rate. In general the values of heritability in broad sense were high for width of leaf lobe (96.73), leaf area (95.68), chlorophyll b (95.01), total chlorophyll (90.41), internodal length (95.71), fresh weight of root (97.42), dry weight of root (95.38), leaf area index (95.68), specific leaf area (98.82), specific leaf weight (97.20), net assimilation rate (99.16), starch (92.78), nonreducing sugar (96.91), total sugar (91.52), $\beta$ carotene (96.57), root tuber girth (91.32), root tuber yield per plant (95.26) and tuber yield per hectare (97.34) indicating that these characters were least influenced by the environmental effects, but the selection for the improvement of such characters may not be useful, because broad sense heritability is based on genetic variance which includes both fixable (additive) and non-fixable (dominance and epistatic) variances. In general, Jones et al., (1986) and Singh and Mishra (1987), Teshome et al., (2004) reported high heritability estimates for the vine traits compared to root traits. But in this study it is more for root traits. Similar results were observed by Madawal (2015) for leaf area index, Jhansirani and Thamburaj (1987), Teshome et al., (2004) for tuber girth; Engida et al., (2007), Gunjanjaha (2008) and Evoor et al., (2008); Engida et al., (2007) for tuber yield per hectare, Sankari et al., (2001) for total sugar and $\beta$ - carotene in sweet potato; Shivanand et al., (2015) for leaf area, leaf area index, specific leaf area, specific leaf weight and net assimilation rate in ridge gourd. Relative growth rate (48.16) recorded moderate value of heritability (30-60\%) indicating the role of non-additive gene action which includes dominance and epistasis. Heritability estimates alone are not of any use in predicting the results about the selection unless it is accompanied by genetic advance (Johnson et al., 1955). The expected genetic advance (EGA) expressed as percentage of mean ranged from 13.96 per cent (Length of leaf lobe) to 278.86 per cent (net assimilation rate). In the present study high value of EGA was observed for these characters width of leaf lobe (96.98), petiole length (34.44), leaf area (152.25), total leaf dry weight (38.16), chlorophyll a (58.80), chlorophyll b (79.35), total chlorophyll (71.00), length of vine (45.47), internodal length (72.04), number of branches per plant (38.74), fresh weight of whole plant (47.74), dry weight of whole plant (43.40), fresh weight of root (76.96), dry weight of root (78.07), leaf area index (152.25), specific leaf area (200.23), specific leaf weight (238.17), crop growth rate (78.70), net assimilation rate (278.86), starch (36.48), reducing sugar (60.07), non-reducing sugar (109.10), total sugar (51.44), $\beta$-carotene (60.37), no. of root tubers per plant (88.20), root tuber length (25.38), root tuber girth (42.49), root tuber yield per plant (98.58), root tuber yield per hectare (86.20) indicating the role of additive gene action and hence, selection is more effective. While moderate value of EGA was recorded for length of leaf lobe (13.96) and relative growth rate (18.30) indicating the role of non-additive gene action. The characters which were observed high to moderate estimates of EGA are indicative of the fact that improvement could be quickly achieved in these characters through selection. Similar findings of high heritability with genetic advance over mean were reported by Teshome et al., (2004), Engida et al., (2007) for length of vine; Kamalam et al., (1977), Choudhary et al., (1999), Gunjanjaha (2008), Teshome et al., (2004), Engida et al., (2007), Hossain et al., (2000) and Evoor et al., (2008) for number of tubers per plant; Choudhary et al., (1999) for tuber length; Engida et al., (2007), Teshome et al., (2004), Choudhary et al., (1999) and Hossain et al., (2000) for tuber yield per hectare. The findings indicates that the existence of adequate genotypic variation in 
the genotypes for width of leaf lobe, leaf area, total leaf dry weight, chlorophyll a, chlorophyll b, total chlorophyll, length of vine, internodal length, number of branches per plant, fresh weight of whole plant, dry weight of whole plant, fresh weight of root, dry weight of root, leaf area index, specific leaf area, specific leaf weight, crop growth rate, net assimilation rate, reducing sugar, non-reducing sugar, total sugar, $\beta$-carotene, number of root tubers per plant, root tuber girth, root tuber yield per plant and root tuber yield per hectare. High PCV, GCV and high heritability coupled with high estimates from genetic gain as percent of mean for width of leaf lobe, petiole length, leaf area, total leaf dry weight, chlorophyll a, chlorophyll b, total chlorophyll, length of vine, internodal length, number of branches per plant, fresh weight of whole plant, dry weight of whole plant, fresh weight of root, dry weight of root, leaf area index, specific leaf area, specific leaf weight, crop growth rate, net assimilation rate, starch, reducing sugar, non-reducing sugar, total sugar, $\beta$-carotene, no. of root tubers per plant, root tuber length, root tuber girth, root tuber yield per plant and root tuber yield per hectare suggesting predominance of additive gene action and lower influence of environmental factors in the expression of these traits with possibility for improvement through selection. Although some of the characters like length of vine, leaf area index, specific leaf area and specific leaf weight are of no importance from consumer point of view, it may be of much importance for a breeder, as they serve as good source of production and supply of sufficient carbohydrates for growth of tubers.

\section{Acknowledgement}

I extend my deep sense of reverence and gratitude to Associate Dean, College of Horticulture, Venkataramannagudem, Dr. Y.S.R.H.U. The germplasm supplied by AICRP on Tuber crops Project, HRS, V.R.
Gudem is greatly acknowledged. I am highly thankful to ICAR for providing financial assistance in the form of stipend to complete this endeavour.

\section{References}

Biradar, R. S., Rajendran P. G. and Hrishi. 1978. Genetic variability and correlation in cassava (Manihot esculenta Crantz). Journal of Root crops. 4(1): 7-10.

Burton, G.W., and Devane, E.H. 1953. Estimating the heritability in tall fescue (Festuca arundinancea) from replicated clonal material. Agronomy Journal. 45: 478-481.

Choudhary, S. C., Harsh Kumar, M., Verma, V. S. and Nasar, S. K. T. 1999. Genetic variability in sweet potato (Ipomoea batatas (L). Lam.). Journal of Applied Biology. 9(2):146-148.

Engida, T., Nigussie, D. and Devakara, E.V. 2007. Genetic variability for yield and other agronomic traits in sweetpotato. Journal of Agronomy. 6 (1): 94-99.

Evoor, S., Patil, M. P., Madalageri, M. B. and Mulge, R. 2008. Genetic variability, heritability and genetic advance in sweet potato (Ipomea batatas L.). Environ. Ecol. 26 (1A): 322-325.

Gunjan, J., 2008. Estimation of genetic variability in sweet potato. The Ecoscan. 41: 180-185.

Hossain, M. D., Rabbani, M. G. and Mollah, M. L. R. 2000. Genetic variability, correlation and path analysis of yield contributing characters in sweet potato. Pakistan Journal of Scientific and Industrial Research. 43(5): 314-318.

Jhansirani, P., and Thanburaj, S. 1987. Genetic variability in sweet potato. South Indian Horiculture. 35 (4): 291293.

Jindal, S.K., Arora, D. and Ghai, T.R. 2010. Variability studies for yield and its 
contributing traits in okra. Electronic Journal of Plant Breeding.1(6): 14951499.

Johnson, H. W., Robinson, H. F. and Comstock, R. S.1955. Estimation of genetic and environmental variability in soybean. Agron journal. 41: 314-318.

Jones, A., Dukes, P.D. and Schalk, J.M. 1986. Sweet potato breeding, p. 1-35. In: M.J. Basset (Ed.). Breeding of vegetable crops. AVI Publishing Company, Westport, Conn.

Kamalam, P., Hrishi, N. and Rajendran, P.G. 1977. Genetic variability in open pollinated progenies of sweet potato. Journal of root crops. 3 (2): 13-23.

Lush, J.L., 1940. Intra-sire correlation on regression off-spring on dams as a method of estimating heritability of characters. Proceedings of American Society of Animal Production. 33: 292301.

Madawal, S. I., Alloli, T. B. Madarakhandi, S. and Narasannavar. A. Genetic Variability study in sweet potato (Ipomoea batatas L.) genotypes. International Journal of Tropical Agriculture. 33(2): 279-282.

Mohanty, P., Ashok, P., Sasikala, K. and Swami, D.V. 2016. Character Association and Path Analyses in Sweet Potato. International Journal of Vegetable Science: 1-14.
Onwueme, I.C., and W.B. Charles. 1994. Production, perspective and future prospects. Tropical root and tuber crops. Plant production and protection paper (126) FAO, Rome: 115-135.

Sankari, A., Thamburaj, S. and Kannan, M. 2001. Genetic variability in Sweet potato. Journal of root crops. 27 (1): 71-73.

Shivanand, B., Koppad., Mukesh, L. Chavan., Jagadeesha, R. C. Vijaykumar, R., Jayappa, J. and Sumangala, K. 2015. Genetic variation and correlations among the physiological growth attributing characters in ridge gourd (LuffaacutangulaRoxb.) with reference to yield. International Journal of Advanced Research, 3(4): 961-971.

Singh, T.R.P., and Mishra, D.N. 1987. Genetic variability in sweet potato (Ipomoea batatas Lam.). Abstract 6: First National Symposium on Root Crops, Trivandrum, India.

Teshome, A., Veeranagavathathan, D., and Kannan, M. 2004. Genetic variability and correlation studies in Sweet potato. Madras Agricultural Journal. 91: 420424.

Thamburaj, S., and Muthukrishnan, C.R. 1978.Association of metric traits and path analysis in sweet potato (Ipomoea batatas (L.) Lam.). Madras Agricultural Journal. 63: 1-8.

\section{How to cite this article:}

Meenakshi Badu, P. Ashok, T.S.K.K. Kiran Patro and Sasikala, K. 2017. Studies on Genetic Variability, Heritability and Genetic Advance for Growth, Yield and Quality Parameters among Orange Flesh Sweet Potato [Ipomoea batatas (L.) Lam.] Genotypes. Int.J.Curr.Microbiol.App.Sci. 6(9): 1894-1903. doi: https://doi.org/10.20546/ijcmas.2017.609.233 